\title{
Irrigation Demand VS Supply-Remote Sensing and GIS Approach
}

\author{
Ch. Ramesh Naidu', M. V. S. S. Giridhar ${ }^{2}$ \\ ${ }^{1}$ GVP College of Engineering (Autonomous), Visakhapatnam, India \\ 2Jawaharlal Nehru Technological University, Hyderabad, India \\ Email: chrnaidu@rediffmail.com, mvssgiridhar@gmail.com
}

Received 9 November 2015; accepted 5 January 2016; published 8 January 2016

Copyright (C) 2016 by authors and Scientific Research Publishing Inc.

This work is licensed under the Creative Commons Attribution International License (CC BY). http://creativecommons.org/licenses/by/4.0/

(c) (i) Open Access

\begin{abstract}
To determine the irrigation requirements of rice crop on different soils, an integrated approach is used using Remote Sensing and GIS techniques. Depending on the type of soil, climate and the crop acreage, the water requirement for paddy fields is derived. This study is focused on estimating the water demand for rice crop in Rabi season. Crop evapo-transpiration and soil percolation losses account more in rice fields especially in hot climate like Rabi season. In addition to evapo-transpiration and percolation losses, the conveyance losses are also accountable in the case of unlined canals. Satellite data is used to estimate the rice and fallow lands. In conjunction to satellite interpreted data, climate and soil data are also integrated in GIS platform. CROPWAT model is used to determine the crop evapo-transpiration $\left(\mathrm{ET}_{\mathrm{c}}\right)$. There are 11 Water User's Associations (WUA) in the command area and under which 13 canal blocks are delineated. These blocks are again delineated in to 212 sub blocks. This study indicates that there exists a $5 \%$ to $20 \%$ of water deficiency in some WUAs and also water surplus in some WUAs varying from $15 \%$ to $40 \%$.
\end{abstract}

\section{Keywords}

GIS, Water Users Association, Evapo-Transpiration, Remote Sensing, Irrigation

\section{Introduction}

The estimation of irrigation demand [1] [2] is an important component for managing the water effectively in the canal command area. To meet the present water demand, irrigation management plays an important role. One of the reasons for low efficiency is the un-accounted volume of water loss due to percolation in the rice fields and conveyance and seepage losses occurred during the water distribution through canals to fields [3] [4]. These losses are accounts in calculating total irrigation demand in addition to crop evapo-transpiration. Traditional way 
of calculating irrigation demand and the absence of scientific approach and adoption of new technologies is another reason for low irrigation efficiency. The selected study area lacks complete information about the command area including its water resources, distribution system details, land use, cropping patterns, soil, geology, climate and socio economic factors and also lacking regular evaluation and working knowledge regarding proper water management. This can be attributed to the dearth of spatially related information available regarding the canal network system and command area. The hard copy printed maps which are currently available are not in scale followed by lack of integration between the maps for the purpose of evaluation. The water allocation in command area is marked by blocks and sub-blocks. These blocks and sub-blocks come under the purview of Water Users' Association (WUA). Proper delineation of block boundaries is essential in order to evaluate water allocation and its usage in terms of actual or theoretical water demand. GIS technology [5] in conjunction with Remote Sensing [6] has proved to be effective for land use and water management. For effective decision making on water use, stresses the need of generation of spatial and non-spatial database in GIS platform [7]. Multispectral and multi-temporal remote sensing data are very useful as input for finding out rice crop acreage and with this, cartographic and data overlaying capability of GIS coupled with its dynamic linking ability plays a vital role in decision making process. Resulting disparities are existed in the availability of water between head-reach and tail end farms and between large and small farms that reflect some portions of the command area posing water shortage and water logging problems due to under and over utilization of canal water. This demands the calculation and analysis of irrigation water requirements of the command area in detail up to water users association, canal block level by using the latest available technologies for optimum utilization of irrigation water.

\section{Materials and Methods}

The selected study area is under block number five left main canal in Nagarjuna Sagar Project [8]. The area is located between $16^{\circ} 39^{\prime} 2.84 "$ and $16^{\circ} 56^{\prime} 40.81^{\prime \prime} \mathrm{N}$ latitude and $79^{\circ} 25^{\prime} 16.01^{\prime \prime}$ and $79^{\circ} 40^{\prime} 52.90^{\prime \prime}$ E longitude. The study area is bounded by Musi River in the East, Krishna River in the South, Lalbahadur canal in the North and Tungapadu vagu in the West. In the command area reserved forest occupies 18 to 20 percent. The command area extends to a total of 26,725 ha, distributed across three mandals namely Mirialguda, Dameracherla and Tripuraram. The methodology adopted for the study involves the use of satellite imagery in conjunction with soil, crop and climate data. Water losses from the field due to seepage and percolation, evapo-transpiration and conveyance losses were estimated. The crop information and statistical reports extracted from satellite imagery were integrated to crop, soil and climate data and the results were analyzed on GIS platform. The flowchart in Figure 1 depicts overall methodology.

Since rice is dominant crop in the study area, multi-spectral and multi-temporal satellite imagery on the basis of crop calendar for Rabi season were procured from National Remote Sensing Centre (NRSC), Hyderabad, India. Imageries in the initial crop development stage and the late mid season stage were selected for the present study. This includes IRS P6 LISS III [9] [10] in the month of February and March. Survey of India (SOI) topomaps in 1:25,000 scale were collected to use as a reference. WUA maps were collected from the Walamtari, Hyderabad and integrated to canal blocks by setting the common projection and converted to GIS format. Figure 2 and Figure 3 shows the maps in GIS platform depicting WUAs in command area and canal distribution on different soils. Collateral data such as soil data, daily meteorological data, and climate and rainfall data were collected from different sources to study the parameters of evapo-transpiration, percolation/seepage loss and conveyance loss. Daily meteorological data was collected from the nearest and most representative meteorological station. Mandal wise daily rainfall data was collected from the District Information Center. Some essential information were collected from the field that includes crop and crop variety, first and last planting date and first and last harvesting date. The satellite imageries after being geo-referenced with respect to SOI topo maps were digitally enhanced to extract appropriate information for rice crop acreage estimates. The crop acreage reports were then generated WUA wise in GIS platform to find out the water demands for each WUA. For this study CROPWAT version 8.0 [11] [12] was used. ETc and Net Irrigation Water Requirements (NIWR) were estimated by using CropPWAT Software. The inputs used at various stages of the software are rainfall, temperature, wind speed, sunshine, sowing and harvesting dates of Rabi, crop factors, rooting depth and soil characteristics of the study area [13] [14]. The effective rainfall and the crop water requirement decide the amount of irrigation water that has to be applied. The effective rainfall is subtracted from the crop water requirement to calculate the 
net irrigation water requirements (NIWR). This formula is taken into consideration while running the CROPWAT model using the daily rainfall data in the program. The net irrigation water requirements have been computed on daily and 10-day basis for each WUA and block/canal [15]. Calculation of the NIWR is carried out by pooling up sequentially the appropriate climate and rainfall data sets together with the crop files and the corresponding sowing/planting dates. In case of NIWR calculation of rice, soil data is also required. NIWR is determined by using the formula: NIWR = ETc - Re. Re is the effective rainfall. The Gross Irrigation Water Requirements (GIWR) [16] required for irrigation gift for the entire command area is equal to the sum of the net irrigation water requirements, water losses due to percolation and seepage and canal conveyance losses.

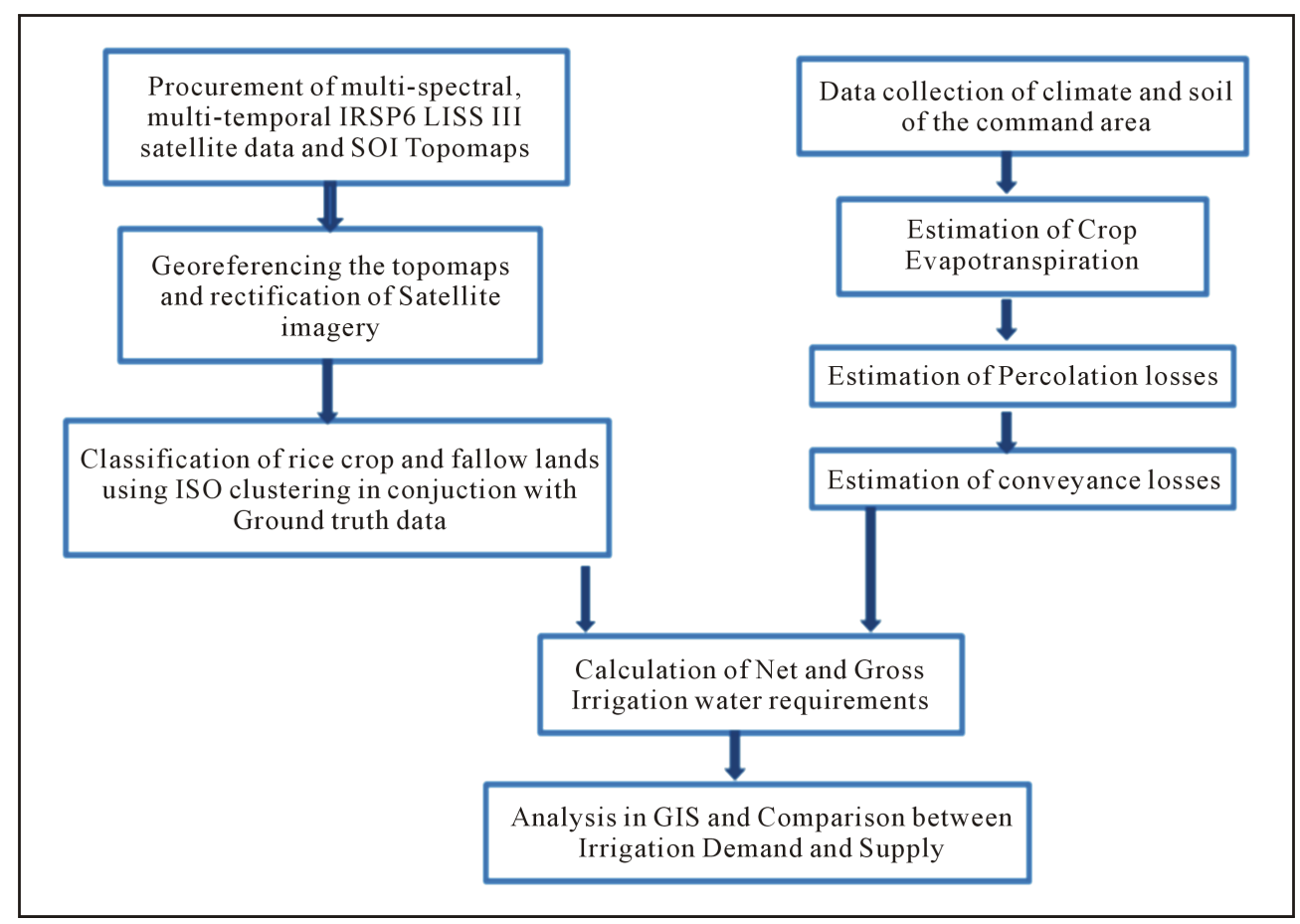

Figure 1. Flow Chart showing the study methodology.

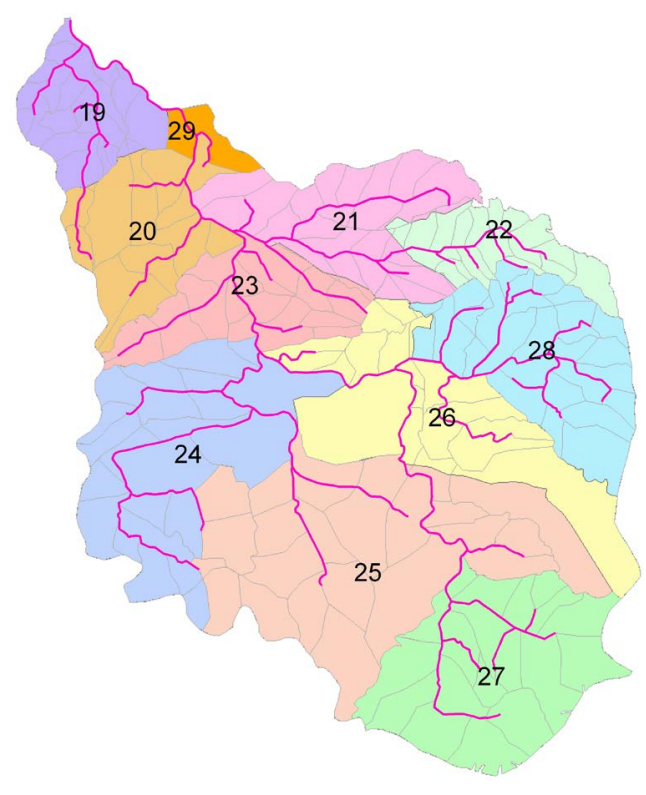

Figure 2. WUA boundaries of command area. 


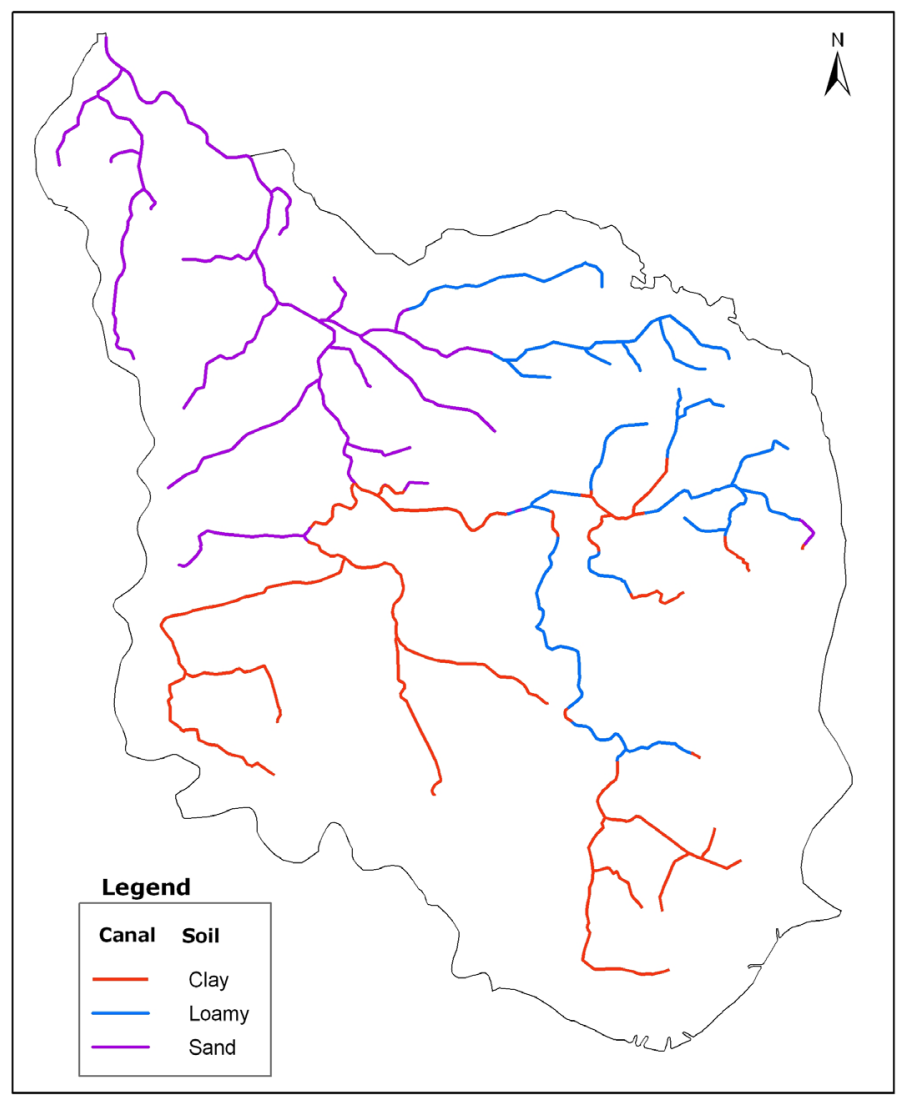

Figure 3. Canals distributed on different soils.

\section{Discussion and Results}

From the results, it was observed that for WUAs of Chillapuram, Venkatadripalem, Kothagudem, Mirialguda and Chinthapalle, the percolation losses accounts more than 10 million litres per ha. Where as for WUAs of Appalammagudem and Kalleyapalle the percolation losses are 5 million litres per ha. For Kondrapole and Kesavapuram WUAs, the percolation losses accounts 7 to 8 million litres per ha. The conveyance losses calculated from GIS ranging from 1 to 25 MLD (million litres per day) per km. Figure 4 and Figure 5 shows WUA wise irrigation demand in the year 2007 and 2009. The percolation losses were calculated using soil, crop, WUA, canal/block themes in the GIS environment using GIS software. Soil type and crop acreage under each command area unit were taken as main parameters for calculation of percolation losses.

The gross irrigation water requirements are compared with the irrigation supplies at WUA level. The study indicates that there is a deficit of water for irrigation in some canal blocks/WUAs, where in water deficiency varies from 5 to 20 percent of total crop water requirement. In some canal blocks and WUAs, water surplus varies from 15 to 40 percent. The data obviously indicates the necessity of additional canal supplies to some blocks and less canal supply to some blocks. Figure 6 and Figure 7 shows the WUA wise irrigation demand versus supply for the year 2007 and 2009. It is observed that at block level or WUA level, the water requirements are not only based on crop extent and also depends on the soil and meteorological conditions of the area. The net irrigation water requirements (NIWR) in the years 2007 and 2009 are 54125 and 85208 million litres. The gross water requirements calculated for the years 2007 and 2009 is 4.875 and 7.25 thousand million cubic feet (TMC). The supply to the command area in both the years is 4.35 and 5.49 thousand million cubic feet (TMC). It indicates the supply is lower than the demand for command area. The study found that there is an excess release of water in the year 2007 for Chillapuram, Kothagudem, Kondrapole, Dameracherla and Kesavapuram WUAs and deficiency of water in Venkatadripalem, Chinthapalle, Borrayapalem, Appalammagudem and Kalleyapalle WUAs. Whereas in the year 2009, the excess water is released for Dameracherla and Mirialguda WUAs and remaining WUAs have deficiency in supply of water to fields. 


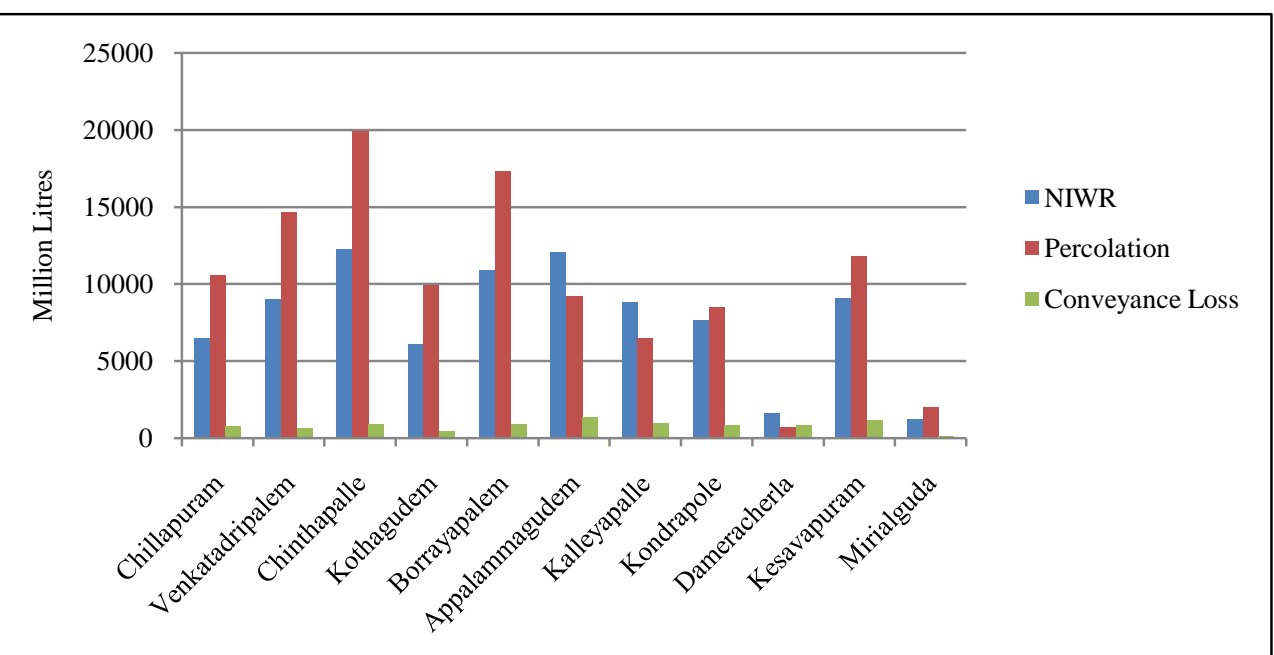

Figure 4. WUA wise irrigation demand in the year 2007.

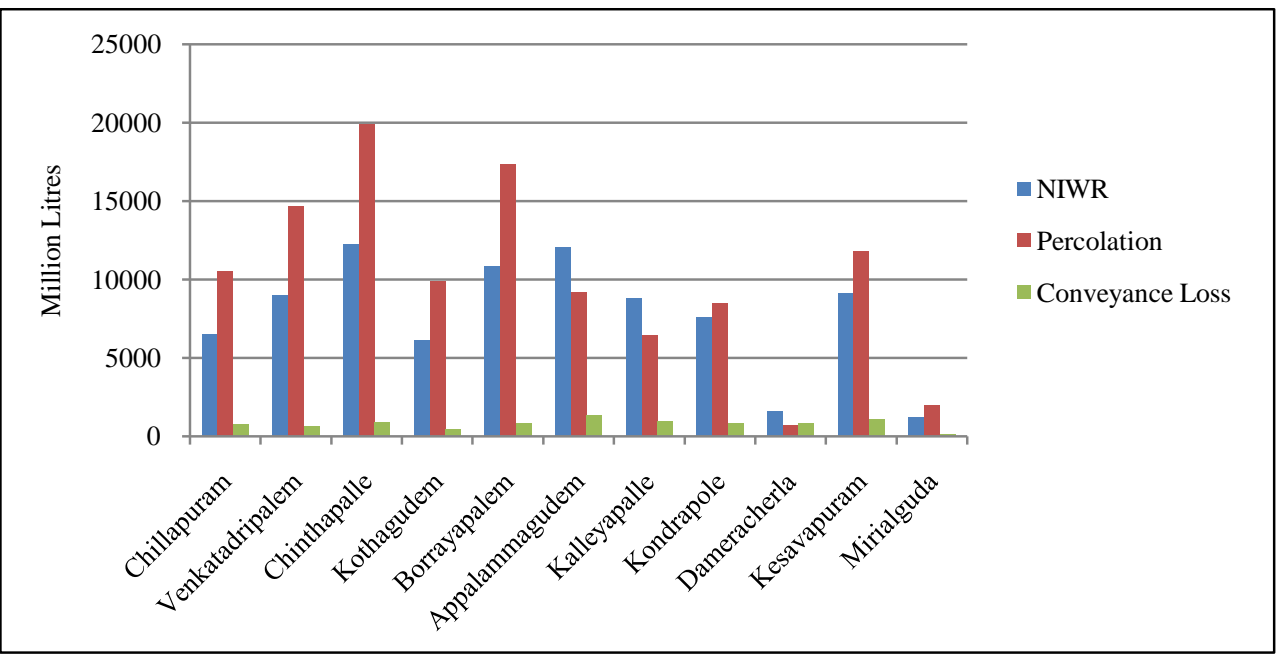

Figure 5. WUA wise irrigation demand in the year 2009.

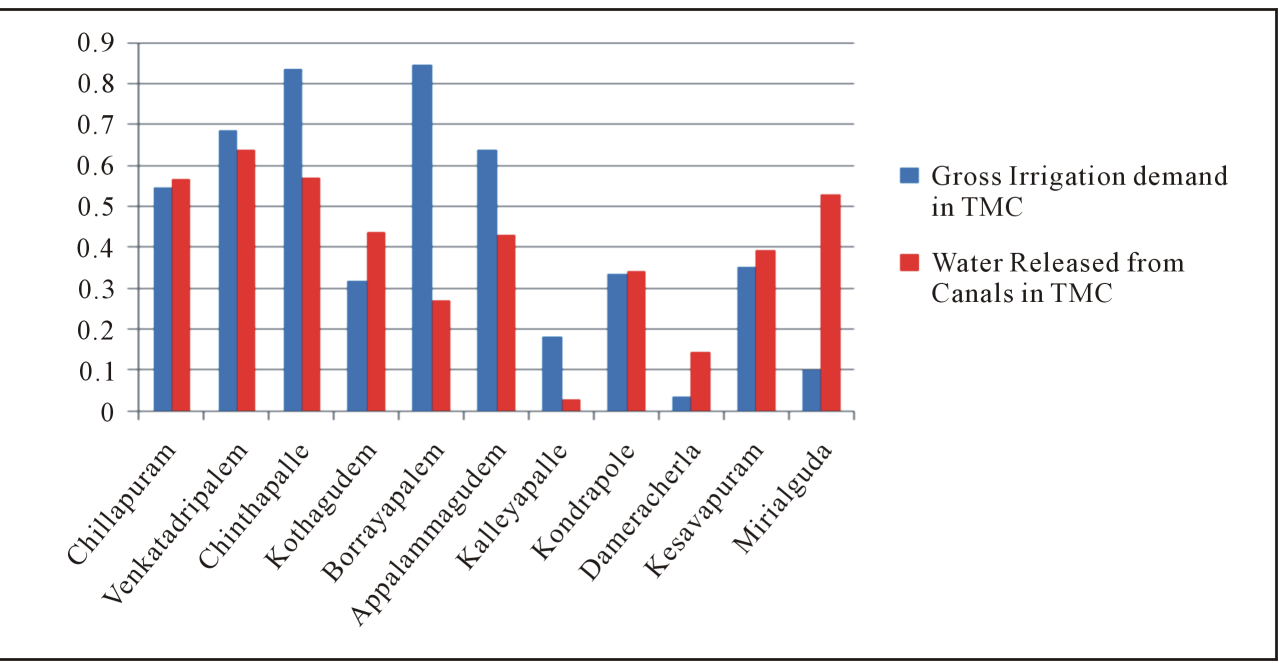

Figure 6. Irrigation demand vs. supply (year 2007). 


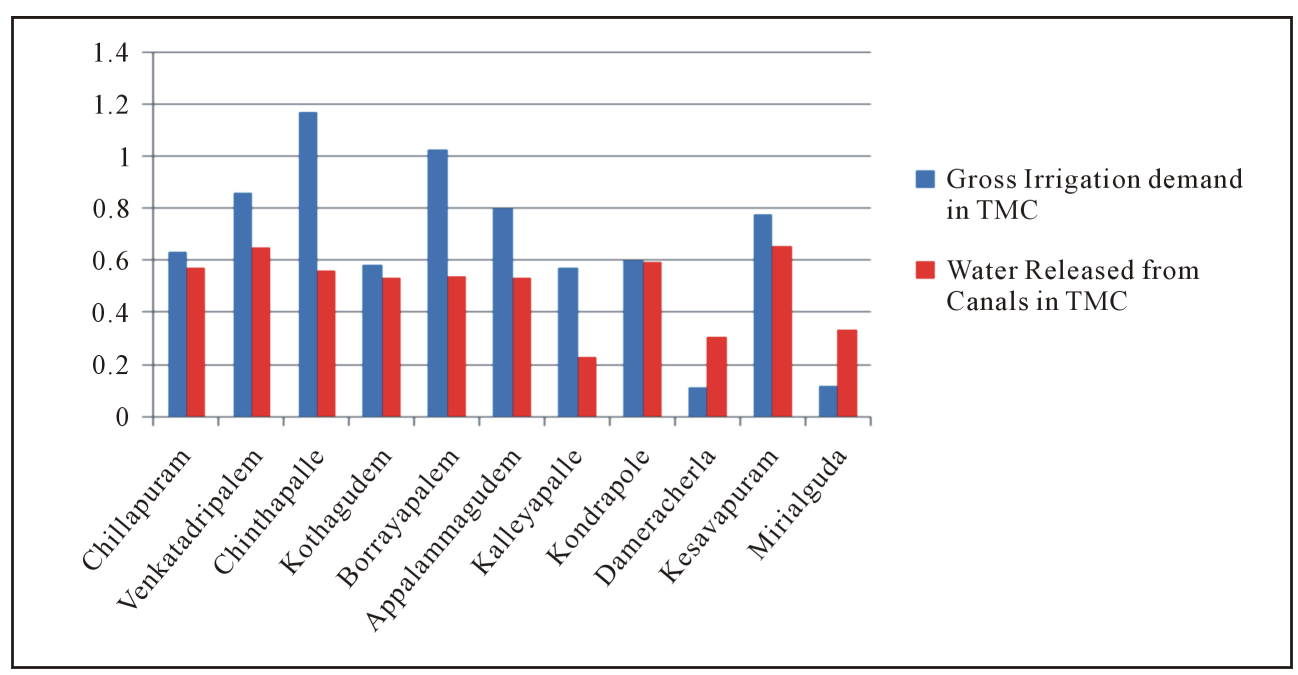

Figure 7. Irrigation demand vs. supply (year 2009).

\section{Conclusions}

From the study, 11 WUAs, 12 canal blocks and 212 canal sub-blocks were delineated under Wazirabad command area in GIS environment. The total command area was calculated in GIS platform as 26,725 hectares (ha). The gross command area was found maximum in Kalleyapalle WUA with 6482 ha and minimum area was found in Mirialguda WUA with 279 ha. In blocks, the maximum gross command area was found in WL5 canal block with 7721 ha and minimum area was in WL1 canal block with 213 ha. Utilizing GIS network model, the total length of the canal system was identified as $155.846 \mathrm{~km}$. The clay soils were predominant and found $49 \%$ in the study area whereas sandy and loamy soils occupied $29 \%$ and $22 \%$ respectively.

The maximum rice crop was identified in Appalammagudem WUA with 1442 ha in the year 2007 and 1884 ha in the year 2009 in a gross command area of 3254 ha. Whereas in Dameracherla WUA, the rice crop was occupied very less area as 20 ha in the year 2007 and 257 ha in the year 2009 out of 3324 ha of gross command area which was situated in tail end of the command area. The increase of area under rice cultivation demands higher water, as a result greater losses were encountered in the command area.

Due to lengthy canal system coupled with low agriculture area (in Dameracherla WUA), the conveyance losses were higher and this created increase in irrigation demand. Significant difference was observed between the sandy and clayey command areas. From the study, it was observed that for WUAs of Chillapuram, Venkatadripalem, Kothagudem, Mirialguda and Chinthapalle, the percolation losses accounted 10 million litres per ha. Whereas for WUAs of Appalammagudem and Kalleyapalle, the percolation losses were 5 million litres per ha. For Kondrapole and Kesavapuram WUAs, the percolation losses accounted 7 to 8 million litres per ha.

\section{References}

[1] Brouwer, C., Hoevenaars, J.P.M. and Van Bosch, B.E., (1992) Scheme Irrigation Water Needs and Supply. FAO, Irrigation Water Management: Training Manual No. 6, 7-43.

[2] El-Magd, I.A. and Tanton, T.W. (2005) Remote Sensing and GIS for Estimation of Irrigation Crop Water Demand. International Journal of Remote Sensing, 26, 2359-2370. http://dx.doi.org/10.1080/0143116042000298261

[3] Palacios, E.V. and Day, J.C. (2012) A New Approach for Estimating Irrigation Conveyance Losses and Their Economic Evaluation. Journal of the American Water Resources Association, 13, 709-720. http://dx.doi.org/10.1080/0143116042000298261

[4] Akkuzu, E., Ünal, H.B. and Karata, B.S. (2002) Determination of Water Conveyance Loss in the Menemen Open Canal Irrigation Network. Turkish Journal of Agriculture, 31, 11-22.

[5] Dadhwal, V.K. (1999) Remote Sensing and GIS for Agricultural Crop Acreage and Yield Estimation. Proceedings of WG VII/2 Workshop on Application of RS and GIS for Sustainable Development, Inter-national Archives in Photogrammetry and Remote Sensing, 7, 58-67.

[6] Jayasekera and Walker (1990) Remotely Sensed Data and Geographic Information System for Management and Ap- 
praisal of Large Scale Irrigation Projects in the Developing Countries. Advances in Planning, Design and Management of Irrigation Systems as Related to Sustainable Land Use, 1453-1461.

[7] Navalgund, R.R. and Ray, S.S. (2000) Geomatics in Natural Resources Management. Proceedings of Geomatics-2000, Pune, NR-1-14.

[8] EPTRI (2008) ISEA Study Report for the Proposed Nagarjuna Sagar Modernization Project. 5-9.

[9] Krishna Rao, M.V., Hebbar, R. and Venkatartnam, L. (1997) Evaluation of IRS-1C Data for Discrimination and Acreage Estimation of Crops Grown under Multiple Cropping Situation. Remote Sensing for Natural Resources, Joint Publication of ISRS \& NNRMS, 205-211.

[10] Dong, Q.H., Herman, E. and Chen, Z.X. (2008) Crop Area Assessment Using Remote Sensing on the North China Plain. Proceedings in ISPRS, 957-962.

[11] Allen, E.A. (1998) Crop Evapotranspiration: Guidelines for Computing Crop Water Requirements. FAO Irrigation and Drainage Paper 56, Rome, 300.

[12] Clarke, D. (1998) CropWat for Windows: User Guide. Version 4.2. University of Southampton, UK.

[13] Giridhar, M.V.S.S. and Viswanadh, G.K. (2005) Estimating of Reference Evapotranspiration for an Irrigation Project Site in Andhra Pradesh, India. Proceedings of International Conference on Environmental Management, JNTU, Hyderabad, 216-223.

[14] Hassan (2005) Estimation of Rice Evapotranspiration in Paddy Fields Using Remote Sensing and Field Measurements. PhD Thesis, Universiti Putra Malaysia, 3-5.

[15] Konex (1996) Mapping the Spatial Distribution of Irrigation Water Requirement for Main Crop Potatoes Using GIS. Agricultural Water Management, 31, 1-15.

[16] Rao, K.V.G.K., Bower, R.C., Gaur, A. and Visvanatha.(1998) Tertiary Level Irrigation System Management in the Chambal Command by Water User Associations. Modernization of Irrigation System Operations: Proceedings of the 5th ITIS Network International Meeting, 214-215. 